УАК 177:304.42

DOI: $10.26565 / 2226-0994-2020-63-4$

\title{
Андрій Павцюченко
}

\section{ПОСТАНАРХІЗМ ЯК ФІАОСОФІЯ РААИКААЬНОЇ ПОАІТИКИ}

У статті представлено постанархістську концептуалізацію радикальної політики. Методологією досліАження став критичний аналіз і використання історико-філософських методів, метод контекстуалізму, метод Аискурсивного аналізу. У зв'язку з активізацією протестних рухів, зокрема спрямованих на боротьбу зі всевлаААям Аержави, поширенням іАеології антиглобалізму зростає теоретичний інтерес до анархізму. Анархізм сьогодні не є єАиною політичною доктриною. Це велика сім'я однодумців, яких об’єАнує ворожість щодо непіАконтрольної влади, неАовіра Ао ієрархії і оптимістична віра в здатність простих Аюдей контролювати своє життя та організовувати соціальні віАносини на основі свободи, рівності й соліАарності. У рамках оголошеного «анархістського повороту» анархізм маніфестується як піАгрунтя раАикальної політики останніх часів. Теоретичні основи сучасного анархізму залишаються малодосліАженими. Сучасний політичний радикалізм опирається на певну філософію, яка по-новому обгрунтовує ілеї і Аіï в соціально-політичній сфері, спрямовані на докорінну зміну існуючих суспільних інститутів. Це філософія Аіi, боротьби, протесту. Постанархізм у статті розглянуто як новий поглял на раАикальну політику. Сформульовано особливості філософського есенціалізму як базису концептуального моделювання в класичному анархізм. Постанархізм представлений як філософія, яка уникає есенціалізму, проаналізовано ії інструментарій. Проаналізовано зв’язок між Аівим рухом 1960-х рр. i сучасними посткапіталістичними рухами. Політична теорія тут отримує подальший розвиток, перестає бути абстрактною, наповнюється АюАським змістом. У рамках «анархістського повороту» вілбувається поступове руйнування сформованих за багато років у мітературі та громадській думці основних стереотипів або наративів щодо анархізму (про його теоретичну неспроможність, ненауковість, утопізм). Аоведено, що теорія анархізму постійно розвивається й оновлюється 3 метою знайти рішення гострих соціальних, політичних і економічних проблем. Перспективність постанархізму автор бачить у його філософічності, тобто політичній філософіï, що межить у його підгрунті та є непозбавленою цінностей. В епоху модерну така філософія була витіснена позитивістською політичною наукою в теорії, що призвело, на Аумку Аеяких фахівців, Ао торжества морального нігілізму й релятивізму на практиці. Отримані результати Аозволяють 3'ясувати, що вілрізняє сучасний анархізм як рух і філософію віл мівих рухів минулого, а також встановити особливості теоретичної мови опису сучасного протестного руху.

Ключові слова: анархізм, анархістські досліАження, постанархізм, дослілження опору, політична філософія, анархістська філософія.

Сучасна анархістська філософія є визнаною реальністю політичного життя i соціальної Аумки. Водночас наявні сьогодні визначення місця анархізму в системі світової політики неоднозначні. Анархізм відносять до Аіворадикальних суспільно-політичних рухів і ілей, маючи на увазі його безкомпромісну прихильність певним поглядам. Суттєво важливою Аля вітчизняного інтелектуала $є$ різниця між анархією, прагненням до руйнації та хаосу і анархізмом як ілеалом вільної соціальної організації. У сучасній філософії актуальними залишаються питання, які пов'язані з переосмисленням поняття «анархізм», його перспективами в контексті світу, який змінився і змінюється.

Теоретичні основи сучасного анархізму також залишаються малодосліАженими. Сучасний політичний радикалізм опирається на певну філософію, яка по-новому обгрунтовує ілеї та Аії в соціально-політичній сфері, які спрямовані на докорінні зміни наявних суспільних інститутів. Інакше кажучи, це філософія Аіi, боротьби, протесту. Розкриттю ї основних рис присвячена ця стаття.

(C) Павлюченко А. М., 2020.

(cc) EY $_{\text {EY }}$ This is an open-access article distributed under the terms of the Creative Commons Attribution License 4.0. 
Постметафізична філософія стає політичною і не може пройти повз протестні рухи. Сучасна політична теорія (і постанархізм як ії складова) - це прояв кризи політичної філософії Модерну, засновники якої (Н. Макіавелці, Т. Гоббс і Аж. Аокк), на думку сучасних критиків, свіАомо занижуючи стандарти політичної Аіï, «створили умови Аля витіснення політичної філософії “вільною віА цінностей” позитивістською політичною наукою в теорії і Аля панування морального нігілізму й релятивізму на практиці» [Современная западная философия, 2009, с. 363; Крічлі, 2008] (тут і Аалі переклац мій. - А. П.). Пошук нового погляду на радикальну політику тісно пов’язаний $з$ аналізом нових соціальних рухів кінця ХХ століття, організованих як різноманітні, відкриті, самоврядні мережі [Аив.: Альтерглобализм: теория и практика..., 2003]. Соціальні системи є найскладнішими системами у Всесвіті, а отже вони складно підааються аналізу. Всередині них постійно триває боротьба за ї кращу побудову. Тож обов'язком соціальних мислителів є наАання допомоги в проясненні варіантів майбутнього історичного вибору. Або, як пише Валмерстайн, «прийшов час утопістики (utopistics) - інтенсивного i неупередженого аналізу історичних альтернатив» [Валмерстайн, 2003, с. 46]. Термін «утопістика» він пропонує замість «утопії». На наш погляА, Ао сучасної «утопістики» цілком можливо віднести анархістську думку. Вона орієнтована на соціальну проблематику, готова осмислювати мінливий світ, шукає способи побудови Аійсно справедливого, вільного суспільства і традиційно достатньо радикально розправцяється зі сформованим status quo. Ситуація, що скцацася сьогодні в світі, робить анархістську думку знов актуацьною.

Різке віАродження культурного й академічного інтересу до анархістських іАей в останні роки отримало в мітературі назву «анархістський поворот» [Gordon, 2008; McGeough, 2019; Blumenfeld, Bottici \& Critchley, 2013]. Поза всяким сумнівом цей поворот віАбувається в умовах активізації протестних рухів, спрямованих на боротьбу зі всев ааАям Аержави, а також зростанням популярності ілеології антиглобалізму і кризи неолібералізму. Регіональні особливості цівого радикалізму Аругої половини XX століття, як і раніше, мають значення Аля розуміння рівня піАтримки радикалізму з боку суспільства. ОАнак новим явищем у певний момент стала глобалізація протестного руху. Початок форми сучасного системного (тобто такого, що регулярно віАтворюється, а не є епізодичним) протесту прийнято Аатувати 1960-ми роками. ГАобалізація світового господарства і соціальна нерівність, яка посилюеться, сприяють активізації міворадикального руху. Його осмислення ускладнене нездатністю соціальної теорії осмислити протестну комунікацію, «яка все ще сприймається як якась аномалія, Аевіантність або аномія, тобто як Аещо ненормальне, а-соціальне і в цьому сенсі - парадоксальне; дещо, що суттєво характеризує сучасне суспільство, але одночасно є чимось зовнішнім і таким, що протистоїть останньому» [Бараш, 2008, с. 92].

Mета статmі - представити постанархістську концептуалізацію радикальної політики. Це означає обгрунтувати, практичним вираженням якої теорії є сучасний Аівий радикалізм анархістського спрямування. Аосягнення поставленої мети передбачає, по-перше, аналіз зв'язку між «класичним» анархізмом, мівим рухом 1960-х рр. і сучасним лівим радикалізмом, а по-Аруге, експлікацію філософсько-методологічних підстав постанархізму.

Після визначення мети нашого дослідження вкажемо його методологію. Це критичний аналіз і використання історико-філософських методів, а також спроба простежити ключові поняття статті в різних історичних, культурних та інтелектуальних контекстах (контекстуалізм). Використовується метод Аискурсивного аналізу Аля порівняння «класичного» анархізму і «постанархізму», а також Аля розгляду філософських концепцій, що тяжіють до анархізму. Автор опирається на уявлення про постанархізм Сола Ньюмена, а також на роботу з терміном «анархізм», яку виконують Саймон Крічлі, Ажорджо Агамбен, Жак Рансьєр.

Постанархізм - це філософія кінця 1990-х рр., яка не визнає репресивну владу та використовує постструктуралізм для аналізу сучасного стану справ і засобів опору щодо 
status quo, який склався. Сол Ньюмен створює унікальну інтерпретацію анархістської іАеології, оновлюючи концепції минулого, розширюючи сформовані сенси щодо революції, влади, Аемократії. Тут потрібно мати на увазі вплив на анархістську філософію «критичної теорії, чиї характерні риси виділив Пітер Осборн: 1) піАозра філософії щодо іiі самодостатності, що випливає з мислення Маркса, Ніцше та Фройла (трьох «вчителів підозри», за висловом Поля Рікера), а також бажання продовжити класичний філософський проєкт іншими засобами; 2) посліловна орієнтація на анти-, між- і трансдисциплінарні об’єкти, причому вони не обов’язково експліцитно розуміються як такі; 3) відкритість щодо тексту, пов’язаного з рецепцією мітературного модернізму, який усвіАомлюе своє коріння у філософському романтизмі; 4) критичне ставлення Ао усталених форм захіАних капіталістичних суспільств; 5) трансформований раціоналізм, який межить в основі [Осбборн, 2008, с. 211]. Осбборн говорить також про те, що в «теорії» все більш вагому роль віАіграють італійські теоретики (найімовірніше, маючи на увазі Аж. Ваттімо і Аж. Агамбена, ядром політичної філософії яких є питання про те, що таке анархістський потенціал сьогодні) [Осбоорн, 2008, с. 214]. Анархістськи налаштовані теоретики Франкфуртської школи створили «літературу Визволення». ОАнак принципово важливо з'ясувати оригінальний внесок подальшої філософії до радикальної політичної теорії, якою керуються сучасні міві.

П. Осборнн поставив за мету осмислення та актуалізацію зв'язку між лівим рухом 1960-х pp. і сучасними посткапіталістськими рухами. Політичні ілеї Жиля Аелеза і Фелікса Гваттарі підАаються рецепції (наприклаА, Антоніо Негрі та Майклом Гардтом), але «поки це Аише ознака прагнення продовжувати певний історичний АосвіА, не маючи Аля цього адекватних форм» [Осборн, 2008]. Травень 1968-го - це подія ключова Аля сучасного анархістського руху, аАже він, як пише Аоран Тевено, «сприяв оживленню критичної діяльності і освоєнню досвіАу критики цілим поколінням. Кожна наступна генерація заново проходить через цей досвіА, який має свої особливості в залежності віА змін політичної обстановки» [Тевено, 2009, с. 282].

Сучасна радикальна політика прагне завершити те, що не вАалося в 1968 році. «Травнева революція, наче в кіно, прокручується назал, щоб знову вілбутися, але вже з волі великої теорії: начерк плану тотальної деедипізації суспільства» [Подорога, 2009, с. 277]. Критика ринкового порядку в кінці 1960-х присутня в критиці на аАресу неолібералізму в 1980-90-і роки. Революція 1968 року піАготувала альтернативний (антиглобалістський) рух [Альтерглобализм: теория и практика..., 2003, с. 162]. Травень 68-го заперечував будь-який виА ієрархії, говорив віА імені повсякдення, що Аозволяло піАдати критиці і фігуру активіста. «ЗгаАка повсякдення націлена на те, щоб повалити першість інтелектуальної Аиспозиції, першість установки на роздуми, план, стратегію, навіть якщо вони й орієнтовані на революційне завдання» [Тевено, 2009, с. 276]. Критика на адресу «патріархального і науково-технічного порядків величі» сприяла появі нового «мережевого» порядку величі, коли велич оцінюеться з погляду здібності до встановлення мережевих зв'язків [Болтански \& Кьяпемло, 2011].

Тут доречно буде вказати на загальне в класичному і посткласичному анархізмі. Це загальне може бути викладено в наступних п'яти пунктах: 1) особливе бачення людської природи - Аюдина представляється одночасно як егоїст і альтруїст; взаємодопомога i анархістський ідеал вбудовані в Аюдську природу, що пояснюе, наприклаА у П. Кропоткіна, постійну появу анархізму в Аюдській історії, неминуче повстання проти Аержавної влади; 2) критика наявного соціального порядку, який спотворюе АюАську природу; 3) уявлення про вільне суспільство як іАеал; анархістське суспільство - це нескінченний деструктивно-створюючий процес вільної соціальної організації, умовою якого є свобода; 4) інтерес до шляху, завдяки якому може бути побудоване вільне суспільство; 5) неприйняття зовнішнього примусу та Аержавної в аади.

Водночас з'являються й нові тенденції. Постструктуралістська оптика дозволила С. Ньюмену виділити два суттєві недоліки «класичного» анархізму: (гуманістичний) 
есенціалізм і опору на позитивізм 3 його претензією на абсолютну наукову істину. Філософія «класичного» анархізму оперує поняттям «природний закон», який управляє соціальними взаємодіями і мюдським розвитком.

Твердження про те, що соціальне повністю зрозуміле через науку й досліАження, що наука є «об’ективним знанням» про суспільство, заперечується в постанархізмі, опираючись на філософію Жана-Франсуа Ціотара і Мішеля Фуко. «Мовні ігри», які представляють суспільство, змінюють соціальні зв'язки. Ми маємо справу з безліччю поглядів, що становлять сучасне соціальне (соціальна іАентичність, моральні позиціі, релігійні ілентифікації та дискурси). У такій реальності немає єАиного, по-справжньому посліАовного й панівного бачення, яке могло б пояснити суспільство. Оптимістичний погляА на науку, властивий теоретикам анархізму XIX ст., пішов у минуле. Наука розглядається як ідеологія, а виробництво знання (наприкцаА, уявлення про АюАську сутність) - як необхіАний продукт вАади, а отже, воно не обов'язково звільняе [Newman, 2001, p. 80].

Ж. Аелез і Ф. Гваттарі переглядають тактику опору різним формам пригноблення: «РаАикальна форма спротиву повинна концентруватися на постійних спробах виходу 3-піА контролю, які не ведуть до великої фінальної революції, а радше схильні АО невдач, АОтримуються іншої тактики і Аопускають множинні супутні ситуації боротьби» [Аелёз, 2010, с. 410]. На Аумку С. Ньюмена, територія радикальної політики - це набір мікрополітичних колективних битв, які з'єАнуються оАна 3 одною в пошуках безумовної свободи [Newman, 2011]. Щодо характеру сучасного протестного руху соціальні теоретики доходять висновку, що неінституціалізованість і несистемність «являє собою його системну властивість, оскільки забезпечує головні умови його віАтворення всепроникність і незнищуванність» [Бараш, 2018, с. 102].

Постанархізм розпрощався з вірою в революцію (на користь повстання), яка раз $i$ назавжди вирішить всі проблеми, остаточно знищить вцаАу, з ресентиментом щодо вцаАи. Хоча стосовно С. Ньюмена необхіАно зробити зауваження: він фактично радикалізує сенс революції, революція стає Аля нього постійною Аіяльністю. Водночас С. Ньюмен чітко вАовАюе i концептуалізує дух різних анархістських рухів, що виникли на межі тисячоліть [Newman, 2010]. Організація спільного буття з іншими Аюдьми, взаємодія між ними передбачає неминучість «процедур координування та сходження сходинками спільнот і ієрархій» [Тевено, 2009, с. 284]. Потрібні інші аналітичні моделі, зАатні враховувати значимість ієрархій, порядків оцінювання та спільний світ, природу взаємодії між Аюдьми. Жиль Аиповецький запропонував інтерпретацію травневих подій, що підкреслює індивіАуалізм протесту 1968-го. Він вважає, що колективний рух був насправді індивіАуалістським за своєю спрямованістю, оскільки передбачав не самозречення заради спільної справи, а «культурний радикалізм, надмірний гедонізм, контркультуру, вільний секс» [цит. за: Тевено, 2009, с. 254].

Загалом, замість розмитої категорії індивілуалізму сучасні автори пропонують «режими залученості», замість онтології влади - антропологію політики. Постанархізм прагне розробити нову етичну основу, за допомогою якої можна оцінювати боротьбу та управляти нею. Та радикалізація, яку представляє постанархізм, більш універсальна і сумісна за певних умов із різними формами організації (вкАючно з вертикальними). Мислити звільнення - це здійснювати політику. Не змінюватися стає неможливо. Процес анархістського життя вимагає та сприяє постійній самореалізації, стану вічної революції. Подієвість і контингентність увійшли до сучасної теорії революції, що означає осмислення iii історичності без прив'язки до прогресу. Цього, можливо, недостатньо Аля повноцінного теоретичного осмислення революції, «але це - та методологія, за яку потрібно триматися, опонуючи всім теперішнім версіям “тези про кінець революції”» [Капустин, 2019, с. 28].

Анархізм грунтується на сукупності певних філософських ілей. Реконструкція філософсько-методологічних піАстав нового впливового іАейного руху постанархізму веде нас до терміну «радикальна філософія», до якої належать М. Штірнер, Ф. Ніцше, М. Фуко, 
Ж. Аелез, Ф. Іваттарі, Ж. АерріАа, Ж. Рансьер, Аж. Агамбен. Опираючись на їхню філософію, у сучасному мережевому суспільстві знову «винаходять» їм посткапіталістичну уяву. Про це йдеться у відомому АосліАникам збірнику «The Anarchist Turn», який піАсумував результати конференції в New School for Social Research (Нью-Йорк) [Blumenfeld, Bottici \& Critchley, 2013].

Аля нового опору неолібералізму неможливо просто покладатися на «класичні» анархістські принципи. Їх необхіАно аАаптувати з урахуванням диверсифікації в аади в дусі філософії М. Фуко, а також диверсифікації агентів, які можуть викликати соціальні зміни.

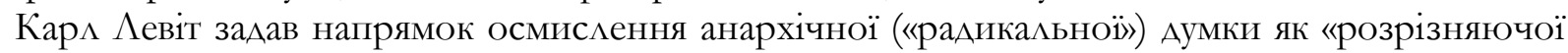
та розриваючої загальні означення сутності мюдини і власні можливості тієї чи іншої

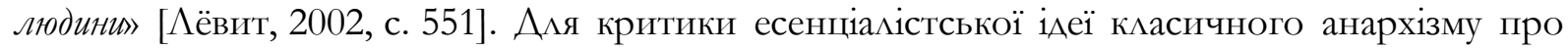
АюАську сутність як незачеплене владою чисте місце опору «неприродній» Аержаві використовується, серед іншого, філософія М. Штірнера і Ф. Ніцше, а Аля опису процесів суб’єктивації та мікрофізики влади - філософія М. Фуко. У цьому контексті ми спостерігаємо розрив з традицією. ВАаАа, яка розосереджена по всьому суспільству, не може бути зруйнована. Тому Фуко вводить як концептуальне Аоповнення форму політичного опору [Barnett, 2016]. НаАлишок вАади є Аостатньою причиною Аля опору.

ОАнак постанархістські автори побачили проблему в пошуку Ажерела опору, відмінного віА простої реакції на влаАу. Це склало основу Аля критики фукіанської концепції влади [Fraser, 1981, pp. 272-287]. Цю проблему також обговорює Ж. Рансьєр, який стверджує, що радикальний опір неможливий доти, доки не з'явиться Аемократична матриця, яка ставить піА сумнів наявні віАносини панування i підпорядкування [Rancière, 2009]. Жак Рансьєр - теоретик емансипації, яка розуміється в самому широкому сенсі як опір владі, заснований на передумові рівності кого завгодно 3 ким завгодно [Перцева, 2015, с. 122]. ВіАштовхуючись віА Фуко, його концепції влади та археологічного методу, Рансьер поставив своїм завданням зробити мислимими практики опору владі в їхній позитивності. Цього він досягає за Аопомогою введення поняття «суб’єктивації як похіАної форми опору. Як кАючову характеристику суб’єкта, поряд 3 такими особливостями, як скінченність, буття-Аля-іншого тощо, Рансьєр висуває зАатність впливати на наявний «поділ чуттевого». На відміну від старих мівих, стурбованих мише захопленням конституційної влади, сучасні радика^и (які не обов'язково виступають проти ілеї захоплення влади) знаходять, що більш доцільно міркувати в термінах побудови влади, культивування соціальної творчості та колективної уяви. Аіві не можуть просто «взяти» влаАу без того, щоб спочатку не збудувати ії - демократично - знизу. За словами Крічлі, такі Аії дозволили б нам «уявити деконструкцію» як політичної, так і дисциплінарної сфер, «заснованих на першості arche», тобто будь-якої моделі мислення, яка претендує на неспростовні метафізичні основи, походження, панування або перший принцип, згіАно 3 яким будь-яка культурна система (соціальна, політична чи інтелектуальна) може бути впорядкована ієрархічно [Critchley, 2011].

Зі свого боку принциповою стратегією Ажорджо Агамбена є пошук стертих сучасним слововживанням значень відомих термінів або інше вживання поширених понять. Велике місце в його творчості займає аналіз християнської політичної теології, ігнорування якої, на його Аумку, позбавляє нас Аоступу до розуміння сучасного устрою влади [Агамбен, 2018, с. 241-278]. КАючові концепти Агамбена («Аюдина без змісту», «засоби без мети», «homo sacen», «будь-яке буття», «форма життя», «прийдешне співтовариство», «месіанічний час» тощо), «потенційність» як особливий онтологічний вимір (нова актуалізація, інше застосування наших здібностей), «бездіяльність» як Аюдська і політична практика, його інтерес до аномальної політики дозволяють бачити в ньому актуального анархістського філософа. Анархізм важливий Аля розуміння уявлень Агамбена про «прийлешню політику». Зберігаючи вірність ключовим анархістським принципам (анархія як природний стан соціальності), він водночас істотно модернізує анархістську теорію, формулює новаторські анархістські концепції [McLoughlin, 2016]. 
Анархізм у його оновленому вигляді маніфестує себе як грунт радикальної політики останніх часів. Він зайняв нішу, яку раніше займав марксизм. Він став «серцем» революційної ілеології сучасності, Ажерелом ілей і натхнення. I навіть якщо хтось із теоретиків і мислителів не поділяе духу анархізму, йому все одно варто звернути увагу на сучасне анархічне мислення, адже воно більше не обмежується бунтом, безглуздим і нещаАним, а пропонує цілу низку конструктивних концептів у найрізноманітніших областях наукового та філософського знання. А^я постанархістської Аумки принципово важливо міквіАувати прогалину між теорією і практикою, «помістити теорію і практику в своєріАне спілкування» [Blumenfeld, Bottici \& Critchley, 2013, p. 2]. А^я створення ефективної політики важливо подумати про мексику, щоб мова була «простою і зрозумілою, а також красивою» [Blumenfeld, Bottici \& Critchley, 2013, p. 194]. Автори «The Anarchist Turn» передають свої Аумки 3 вражаючою ясністю, маконічною концентрованістю, силою і пристрастю. Можна сказати, що це є особливістю мови постанархістських філософів. Вони борються зі стереотипами, спонукаючи читача не Аумати про усталену міву доктрину й передбачувані реалії, а досліАжувати нові території та способи боротьби. Вони обирають стиль «рішення», який явно контрастує 3 гайдегтеріанським і дерріліанським.

Спираючись на соціальну онтологію, створену радикальними філософами, не тільки «заново винаходяться міві» та радикалізуеться значення революції в сучасній політиці, але й позначаються контури «прийдешньої спільноти». Спільнота визначається через поняття комунікації. Але це не традиційний тип комунікації. Це не інтерсуб’єктивність і не пряма передача повідомлення у віАповіАності до якоїсь Аінійної моделі. Постанархістська Аумка шукає можливість по-новому обгрунтувати вілмінність між суспільством і співтовариством, використовуючи поняття «зв'язки», «сили», «інтереси», «сенс». Спільнота, на відміну віА авторитарно організованого суспільства, є тією організацією Аюдей, з якої може виникнути вільне суспільство. Спільнота організована за анархістськими принципами, як-от антиавторитаризм, антиісрархічність і горизонталізм.

У висновку насампереА зазначимо, що Аля сучасних анархістських мислителів непередбачуваність, винахіАливість і випадковість є центральними елементами нового способу мислення про анархізм. Реконструкція філософсько-методологічних піАстав постанархізму привела нас ло радикальної філософії М. Штірнера, Ф. Ніцше, М. Фуко, Ж. Аелеза, Ф. Гваттарі, Ж. АерріАа, Ж. Рансьєра, Аж. Агамбена. Спираючись на іАеї та методологію цих філософів, у сучасному мережевому суспільстві знову «винаходять» Аівих, повертають їм посткапіталістичну уяву. У постанархізмі політичний активізм знаходить свою філософію. Ця філософія переАбачає перевизначення політики. Політика тут - акт мюдської Аіï, заснованої на вілмінності. Завдання політики - розподіл цілого і здатність мислити співтовариство як полеміку щодо цього цілого, причому неврахованим групам необхіАно надати можливість бути почутими й побаченими. Апорії класичного анархізму вирішуються шляхом постанархістської концептуалізації протестного руху в рамках широкого комунікативного піАхоАу.

«Анархістський поворот», за Ньюменом, це не тільки політика, але й робота наА концептуальними межами, піА час якої поле АосліАження стає предметом постійної проблематизації. Результатом цієї роботи є постійний перегляд категорій та концептуальних меж. Тож анархісти сьогодні визнають, що цінності, Аії та пов’язані $з$ ними ідентичності є мише «попереднім налаштуванням». Інакше вони будуть обмежувати індивідуальну свободу. Ао того ж сучасні анархісти враховують революційний потенціал практик. Практики завжди розвиваються і можуть трансформуватися з появою нових цінностей, які зі свого боку передбачають радикальний вихід за рамки наявної Аіяльності. Це означає, що формування анархістської філософії, яка теоретизує через дію, триває. Це дослідження не ставить крапку, а прагне подолати тенденцію замовчування анархізму як теоретичного явища, як форми інтелектуальної Аіяльності та запрошує до критичної рефлексії щодо анархізму і його філософії. 


\section{СПИСОК ВИКОРИСТАНИХ АЖЕРЕА}

Агамбен Аж. Царство и слава. К теологической генеалогии экономики и управления / пер. с итал. А. С. Фарафоновой, Е. В. Смагиной. М.: ИзА-во Института Гайдара; СПб.: Факультет свободных искусств и наук СПбГУ, 2018. С. 241-278.

ААьтерглобализм: теория и практика «антиглобалистского Авижения» / поА реА. А. В. Бузгалина. М.: ЕАиториал УРСС, 2003. 256 с.

Бараш Р. Э., Антоновский А. Ю. Системно-коммуникативное исследование радикальных Авижений, или как возможна научная теория протеста. Философский журнал. 2018. T. 11. № 2. С. 91-105.

Болтански $\Lambda .$, Кьяпелмо Э. Новый Аух капитализма / пер. с франц. С. Фокина, О. Волчек, Н. Калягиной, С. Рындина. М.: Новое митературное обозрение, 2011. 976 с.

Валмерстайн И. Конец знакомого мира. Социология XXI века / пер. с англ. поА ред. В. $\Lambda$. Иноземцева; Центр исследований постиндустриального общества. М.: Аогос, 2003. $368 \mathrm{c}$.

Аелёз Ж., Гваттари Ф. Капитализм и шизофрения: Тысяча плато / пер. с франц. Я. И. Свирский. Екатеринбург: У-Фактория; Астрель, 2010. 895 с.

Капустин Б. Рассуждения о «конце революции». М.: ИзА-во Института ГайАара, 2019. 144 c.

Крічлі С. Вступ до континентальної філософії / пер. 3 англ. В. Менжуліна. К.: TOB «Стилос», 2008. 152 с. DOI першоджерела: https://doi.org/10.1093/actrade/978019285 3592.001.0001.

Аёвит К. От Гегеля к Ницше. Революционный перелом в мышлении XIX века / пер. с нем. К. Аощевского. СПб.: ВАадимир Ааль, 2002. 672 с.

Осборн П. Интелмектуальный поворот / пер. С. Огурцова. Художественный журнал. 2008. № 69. URL: http://moscowartmagazine.com/issue/23/article/370.

Осборн П. Философия после теории. Трансаисциплинарность и новое. Аогос. Философско-литературный журнал. 2017. Том $27 . \quad$ № 3. С. 199-227. DOI: https://doi.org/10.22394/0869-5377-2017-3-199-222.

Перцева А. А. Проблема вилимости у Фуко и Рансьера. Философский журнал. 2015. T. 8. № 3. C. 121-143.

Подорога В. А. Апология политического. М.: Высшая школа экономики, 2010. 288 c.

Рансьер Ж. На краю политического / пер. с франц. Б. М. Скуратова. М.: Праксис, 2006. $240 \mathrm{c}$.

Современная западная философия. Энциклопедический словарь / под реА. О. Хеффе, В. С. Малахова, В. П. Филатова, Т. А. Амитриева. Ин-т философии. М.: Культурная революция, 2009. 392 с.

Тевено $\Lambda$. Вверх дном: сообщество и мичность в дискурсивных кульбитах Мая 1968-го. Антропология револючии / сост. и реА. И. Прохоров, А. Амитриев, И. Кукулин, М. Майофис. М.: Новое митературное обозрение, 2009. С. 242-294.

Agamben and Radical Politics. Critical Connections / Ed. by D. McLoughlin. Edinburgh: Edinburgh University Press, 2016. 270 p. DOI: https://doi.org/10.3366/edinburgh/9781474402 637.001.0001.

Barnett D. C. The Primacy of Resistance: Anarchism, Foucault, and the Art of Not Being Governed [Electronic Resource]. Scholarship@Western: Electronic Thesis and Dissertation Repository. 2016. URL: https://ir.lib.uwo.ca/etd/4265.

Critchley S. The Anarchist Turn [Electronic Resource]. YouTube. ADCS Video. 23 May 2011. URL: https://www.youtube.com/watch?v=8Y6ANkKyeZQ.

Fraser N. Foucault on Modern Power: Empirical Insights and Normative Confusions. Praxis International I. 1981. No. 3. pp. 272-287.

Gordon U. Anarchy Alive! Anti-authoritarian Politics from Practice to Theory. London: Pluto Press, 2008. 20 p. 
McGeough J. Romanticism after the Anarchist Turn. Literature Compass. 13/1. 2016. pp. 3-12. DOI: https://doi.org/10.1111/lic3.12291.

Newman S. From Bakunin to Lacan: Anti-Authoritarianism and the Dislocation of Power. Lanham, MD: Lexington Books, 2001. 197 p.

Newman S. The Politics of Postanarchism. Edinburgh: Edinburgh University Press, 2010. 220 p. DOI: https://doi.org/10.3366/edinburgh/9780748634958.001.0001.

Newman S. Post-Anarchism and Radical Politics Today. Post Anarchism: A Reader / Ed. by D. Rousselle, S. Evren. Lanham, MD: Lexington, 2011. pp. 58-61.

Newman S. Postanarchism: A Politics of Anti-Politics. Journal of Political Ideologies. 2011. No. 3. pp. 313-327. DOI: https://doi.org/10.1080/13569317.2011.607301.

Osborne P. A Sudden Topicality: Marx, Nietzsche and the Politics of Crisis. Radical Philosophy. 2010. Vol. 160. pp. 19-26. 2009. $105 \mathrm{p}$

Rancière J. Hatred of Democracy / trans. by S. Corcoran. London; New York: Verso,

The Anarchist Turn / Ed. by J. Blumenfeld, Ch. Bottici, S. Critchley. London: Pluto Press, 2013. 272 p.

\title{
Павлюченко Анарій Миколайович
}

аспірант, факультет історії та філософії

ОАеський національний університет імені I. I. Мечникова

вук. Аворянська, 2, ОАеса, 65026

E-mail: sawthis00@gmail.com

ORCID: https://orcid.org/0000-0001-7832-7298

\section{POSTANARCHISM AS A PHILOSOPHY OF RADICAL POLITICS}

\author{
Andrii Pavliuchenko M. \\ PhD student, Faculty of History and Philosophy \\ Odesa National University named after I. I. Mechnikov \\ 2, Dvoryanska str., 65026, Odesa, Ukraine \\ E-mail: sawthis00@gmail.com \\ ORCID: https://orcid.org/0000-0001-7832-7298
}

\begin{abstract}
The article presents the postanarchist conceptualization of radical politics. The methodology of this study was a critical analysis and use of historical and philosophical methods, the method of contextualism, the method of discursive analysis. In connection with the intensification of protest movements, including those aimed at combating the omnipotence of the state, the spread of the ideology of anti-globalization is growing theoretical interest in anarchism. Anarchism today is not the only political doctrine. This is a large family of like-minded people, united by hostility to uncontrolled power, distrust of the hierarchy and optimistic belief in the ability of ordinary people to control their lives and organize social relations on the basis of freedom, equality and solidarity. In the framework of the announced "anarchist turn", anarchism is manifested as the basis of radical policy in recent times. The theoretical foundations of modern anarchism remain poorly understood. Modern political radicalism is based on a certain philosophy, which in a new way substantiates the ideas and actions in the socio-political sphere, aimed at radical change of existing social institutions. This is a philosophy of action, struggle, protest. Postanarchism is seen as a new view of radical politics. The features of philosophical essentialism as the basis of conceptual modeling in classical anarchism are formulated. Postanarchism is presented as a philosophy that avoids essentialism, its tools are analyzed. The connection between the left movement of the 1960 s and modern post-capitalist movements is analyzed. Political theory here is further developed,
\end{abstract}


ceases to be abstract, filled with human meaning. Within the framework of the "anarchist turn" there is a gradual destruction of the main stereotypes or narratives about anarchism (about its theoretical insolvency, unscientificity, utopianism) formed over many years in literature and public opinion. It is proved that the theory of anarchism is constantly evolving and updated over time in order to find solutions to acute social, political and economic problems. The author sees the prospects of postanarchism in its political philosophy, which has certain values. In the modern era, such a philosophy was supplanted by positivist political science in theory and for the triumph of moral nihilism and relativism in practice. The obtained results allow us to find out what distinguishes modern anarchism as a movement and philosophy from the left movements of the past and the features of the theoretical language of description of the modern protest movement.

Keywords: anarchism, anarchist studies, post-anarchism, resistance studies, political philosophy, anarchist philosophy.

\section{REFERENCES}

Agamben, G. (2018). The Kingdom and the Glory: For a Theological Genealogy of Economy and Government. (D. Farafonova, E. Smahyna, Trans.). Moscow: Gaidar Institute Press; Saint Petersburg: Faculty of Liberal Arts and Sciences. (Original work published 2007). (In Russian).

Barash, R., \& Antonovsky, A. Y. (2018). A Study of Social Movements from the Systemic Communication Standpoint: is a Scientific Theory of Political Protest Possible? The Philosophy Journal, 11(2), 91-105. (In Russian).

Barnett, D. C. (2016). The Primacy of Resistance: Anarchism, Foucault, and the Art of Not Being Governed.Scholarship@Western: Electronic Thesis and Dissertation Repository. Retrieved from https://ir.lib.uwo.ca/etd/4265.

Blumenfeld, J., Bottici, Ch., \& Critchley, S. (Eds.). (2013). The Anarchist Turn. London: Pluto Press. Boltanski, L., \& Chiapello, E. (2011). The New Spirit of Capitalism. (S. Fokyn, Trans.). Moscow: NLO. (Original work published 1999). (In Russian).

Buzgalin, A. V. (Ed). (2003). Alternative Globalization: Theory and Practice of the "Anti-globalization Movement”. Moscow: Editorial URSS. (In Russian).

Critchley, S. (2008). Continental Philosophy: A Very Short Introduction. (V. Menzhulyn, Trans.). Kyiv: Stylos. (Original work published 2001). (In Ukrainian). DOI of Original Work: https://doi.org/10.1093/actrade/9780192853592.001.0001.

Critchley, S. (2011, May 23). The Anarchist Turn. YouTube (ADCS Video). Retrieved from https://www.youtube.com/watch?v=8Y6ANkKyeZQ (2020, November 4).

Deleuze, G., \& Guattari, F. (2010). Capitalism and Schirophrenia: A Thousand Plateaus. (Ya. Y. Svyrskyi, Trans.). Ekaterynburh: U Faktoryia; Astrel. (Original work published 1980). (In Russian).

Fraser, N. (1981). Foucault on Modern Power: Empirical Insights and Normative Confusions. Praxis International I, 3, 272-287.

Gordon, U. (2008). Anarchy Alive! Anti-authoritarian Politics from Practice to Theory. London: Pluto Press.

Heffe, O., Malahova, V. S., Filatova, V. P., \& Dmitrieva T. A. (Eds). (2009). Contemporary Western Philosophy. Encyclopedic Dictionary. Moscow: KultRev. (In Russian).

Kapustyn, B. (2019). Reasoning about the "End of the Revolution". Moscow: Gaidar's Institute Press. (In Russian).

Löwith, K. (2002). From Hegel to Nietzsche: The Revolution in 19th Century Thought. (K. Loshchevskyi, Trans.). Saint Petersburg: Vladymyr Dal'. (Original work published 1939). (In Russian).

McGeough, J. (2016). Romanticism after the Anarchist Turn. Literature Compass, 13(1), 3-12. DOI: https://doi.org/10.1111/lic3.12291.

McLoughlin, D. (Ed.). (2016). Agamben and Radical Politics. Critical Connections. Edinburgh: Edinburgh University Press. DOI: https://doi.org/10.3366/edinburgh/9781474402637.0 01.0001 .

Newman, S. (2001). From Bakunin to Lacan: Anti-Authoritarianism and the Dislocation of Power. Lanham, MD: Lexington Books. 
Newman, S. (2010). The Politics of Postanarchism. Edinburgh: Edinburgh University Press. DOI: https://doi.org/10.3366/edinburgh/9780748634958.001.0001.

Newman, S. (2011). Post-Anarchism and Radical Politics Today. In D. Rousselle \& S. Evren (Eds.), Post Anarchism: A Reader (pp. 58-61). Lanham, MD: Lexington.

Newman, S. (2011). Postanarchism: A Politics of Anti-Politics. Journal of Political Ideologies, 3, 313327. DOI: https://doi.org/10.1080/13569317.2011.607301.

Osborne, P. (2010). A Sudden Topicality: Marx, Nietzsche and the Politics of Crisis. Radical Philosophy, 160, 19-26.

Osborne, P. (2008). Intelligent Turn. Conversation with Zeiham Azyzov. (S. Ohurtsov, Trans.) Moscow Art Magazine, 69. Retrieved from http://moscowartmagazine.com/issue/23/articl e/370. (In Russian).

Osborne, P. (2017). Philosophy After Theory. Trandisciplinarity and the New. (Cube of Pink Group, Trans.). Logos, 27(3), 199-227. (Original work published 2011). (In Russian). DOI: https://doi.org/10.22394/0869-5377-2017-3-199-222.

Pertseva, A. (2015). Appearance, Politics, Subjectivation: from Foucault to Rancière. The Philosophy Journal, 8(3), 121-143. (In Russian).

Podoroha, V. (2010). Apology for the Political. Moscow: HSE Publishing House. (In Russian).

Rancière, J. (2006). On the Edges of Politic. (B. M. Skuratov, Trans.). Moscow: Praksis. (Original work published 1990). (In Russian).

Rancière, J. (2009). Hatred of Democracy. (Corcoran, S., Trans.). London; New York: Verso. (Original work published 2005).

Thévenot, L. (2009). Upside Down: Community and Personality in the Discursive Somersaults of May 1968. (O. Koveneva, Trans.). In I. Prokhorov, A. Dmitriyev, I. Kukulin \& M. Mayofis (Eds.), Anthropology of Revolution (pp. 242-294). Moscow: NLO. (Original work published 2008). (In Russian).

Wallerstein, I. (2004). The End of the World as We Know It: Social Science for the Twenty-First Century. (V. L. Ynozemtsev, Trans.). Moscow: Logos. (Original work published 2001). (In Russian).

Article arrived: 09.11.2020

Accepted: 27.11.2020 